\title{
MORPHOMETRIC STUDY OF PTERION AND ASTERION IN ADULT HUMAN SKULLS OF INDIAN ORIGIN
}

\author{
Vivaan Dutt ${ }^{* 1}$, Veena Vidya Shankar ${ }^{2}$, Shailaja Shetty ${ }^{3}$. \\ ${ }^{1}$ MBBS, Ramaiah Medical College, Bangalore, Karnataka, India. \\ ${ }^{2}$ MBBS, MD, Associate Professor, Department of Anatomy, Ramaiah Medical College, Bangalore, \\ Karnataka, India.
}

${ }^{3}$ MBBS, MD, Professor and Head, Department of Anatomy, Ramaiah Medical College, Bangalore, Karnataka, India.

\section{ABSTRACT}

Introduction: The pterion and asterion are regions of sutural confluence in the skull. They represent important extra-cranial landmarks allowing surgical and microsurgical approach for surgeons.

Aims: To study the morphology and morphometry of the pterion and asterion in the adult human skulls of Indian origin.

Materials and methods: 78 dry human skulls were studied. Sutural pattern of pterion were classified into sphenoparietal, frontotemporal, epipteric or stellate type. Position of pterion was determined in relation to four specific bony landmarks. Length and thickness were also measured using slide calipers. Sutural morphology of asterion was classified.

Results: All four types of pterion were observed in the skulls analyzed. Sphenoparietal was the predominant type observed. Stellate type was least common. Bilateral asymmetry was seen. Mean distances from centre of pterion were 38.15+/-3.67 (right side) and 36.69+/-3.64 (left side) superior to zygomatic arch; $29.35+/-3.60$ (right side) and $27.37+/-5.80$ (left side) posterior to fronto-zygomatic suture, $8.80+/-2.25$ (right side) and $8.66+/-2.21$ (left side) from lateral edge of sphenoidal ridge and 39.58+/-3.49(right side) and 38.84+/-3.48 (left side) from lateral margin of optic canal. Mean length of pterion was $14.06+/-2.96$ on right side and $14.58+/-4.06$ on left side. Mean thickness of skull at pterion was $5.72+/-1.41$ on right side and 5.77+/-1.29 on left side. Type 1 and type 2 of asterion were observed in the skulls.

Conclusion: The present study is in agreement with previous studies on different populations and concludes that the morphologic and morphometric patterns of pterion and asterion in skulls of Indian origin are similar to those in other populations.

KEY WORDS: Pterion, asterion, morphometry, skull, frontozygomatic suture, sutural bones, sphenoparietal.

Address for Correspondence:Dr. Vivaan Dutt, Ramaiah Medical College, Bangalore - 560054, Karnataka, India. Contact No.: 09901060041, E-Mail: vivaan00@gmail.com

\begin{tabular}{|c|c|c|}
\hline \multicolumn{3}{|c|}{ Access this Article online } \\
\hline \multirow{2}{*}{ Quick Response code } & \multicolumn{2}{|c|}{$\begin{array}{l}\text { Web site: International Journal of Anatomy and Research } \\
\text { ISSN 2321-4287 } \\
\text { www.ijmhr.org/ijar.htm }\end{array}$} \\
\hline & $\begin{array}{l}\text { Received: } 23 \text { Mar } 2017 \\
\text { Peer Review: } 23 \text { Mar } 2017\end{array}$ & $\begin{array}{l}\text { Accepted: } 25 \text { Apr } 2017 \\
\text { Published (O): } 31 \text { May } 2017\end{array}$ \\
\hline DOI: 10.16965/ijar.2017.198 & Revised: None & Published (P): 31 May 2017 \\
\hline
\end{tabular}

\section{INTRODUCTION}

The pterion is a region of sutural confluence in the Norma lateralis of the skull where the frontal, parietal, squamous part of temporal and greater wing of sphenoid bones meet. It lies in the anterior part of floor of the temporal fossa about $4 \mathrm{~cm}$ above the zygomatic arch \& $3.5 \mathrm{~cm}$ behind the fronto-zygomatic suture [1].

It represents an important extra-cranial landmark for surgeons, as it allows surgical and 
microsurgical approach to - anterior branch of middle meningeal artery, Broca's motor speech area on the left side, the Sylvian fissure, internal capsule, optic canal, orbit, and sphenoidal ridge $[2,3]$. The pterion is also used as a guide for age estimation and sex determination on the basis of suture closure [4]. The region of the pterion occurs as the membranous antero-lateral fontanelle during fetal life and at birth, and generally ossifies completely after birth [5]. The presence of sutural bone at the pterion site is thought to be a surgical pitfall as a burr hole placed over it may cause inadvertent penetration into the orbit [6]. The fronto temporal craniotomy, also known as pterional craniotomy is the commonest neurosurgical approach for microsurgical clipping of intracranial aneurysms - almost all aneurysms of anterior circulation \& a few of the basilar artery aneurysms [7].

The asterion refers to the junction of the parietal, mastoid part of temporal and occipital bones of the skull, seen in Norma occipitalis. It is also an important surgical landmark for the posterior cranial fossa, corresponding to the location of the transverse sinus [1].

Objectives: The morphologic and morphometric study of type and location of the pterion and asterion have clinical relevance, and forms the basis for this study, which aims to enhance the knowledge on the prevalence of different types of pterion and its relative position on the skull, and the types of asterion, in the Indian setting.

\section{MATERIALS AND METHODS}

Study design: Cross-sectional study

Place of study: Ramaiah Medical College, Bengaluru.

Duration of study: 3 months - two months for data collection \& one month for data analysis

Sample Size: Based on previous studies, 78 dry human skulls of Indian origin, of unknown age and sex, were studied with an expected proportion of 0.91 (or $91 \%$ ), relative precision of $7 \%$ and desired confidence level of $95 \%$.

Source of data: Human skulls in Department of Anatomy at Ramaiah Medical College, Bengaluru

Inclusion Criteria - Only those skulls which were regular in shape, with no obvious deformity or malformation, and with the calvarium separated above the level of pterion were selected

Exclusion Criteria: Skulls with bilateral absence of pterion, due to breakage or synostosis.

Parameters: The following parameters were observed in pterion and asterion

\section{Pterion}

Type of pterion: Type (sutural pattern) of pterion was classified in accordance with Murphy's criteria, into one of 4 types-sphenoparietal, frontotemporal, epipteric or stellate.

Position of pterion: Position of pterion was determined in relation to four specific bony landmarks in the skull. A circle of smallest diameter was drawn which passed through all the 4 bones converging at the pterion. Linear distances were measured from the midpoint of this circle to the following specific bony landmarks

P-ZA-from centre of pterion to superior margin of zygomatic arch

P-FZS-from centre of pterion to posterolateral margin of the frontozygomatic suture.

P-OC-centre of pterion on internal aspect of skull to lateral margin of optic canal

P-SR-centre of pterion on internal aspect of skull to lateral end of sphenoidal ridge on sphenoid bone.

Length of the pterion: Measured along line of articulation of sphenoid and parietal bones in case of sphenoparietal type of pterion and between frontal and temporal bones in case of frontotemporal type of pterion. This parameter is inapplicable in case of epipteric and stellate type.

Thickness of skull at pterion was also measured, at the centre of pterion.

All the above mentioned measurements were made using a digital slide caliper ("Yamayo Digimatic Caliper-Classic"), with least count of $0.01 \mathrm{~mm}$. All parameters were evaluated bilaterally, observations tabulated and analyzed.

Asterion: Sutural morphology of asterion was classified as T1 (presence of a sutural bone at asterion) and T2 (absence of sutural bone at asterion)

\section{Statistical Analysis:}

Data was tabulated in a MS Excel data sheet, and quantitative parameters of frequency and 
mean (and median, where applicable) of linear distance, calculated using the same.

The Chi-square test was used for the analysis of the data.

Fig. 1: Sphenoparietal type of Pterion.

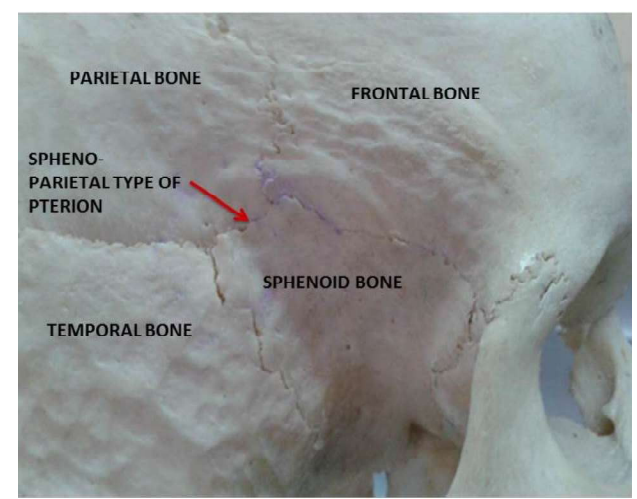

Fig. 2: Frontotemporal type of Pterion.

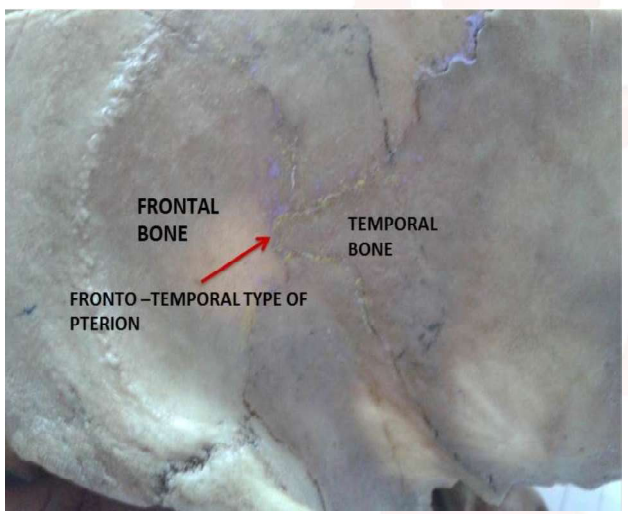

Fig. 3: Epipteric bone at Pterion.

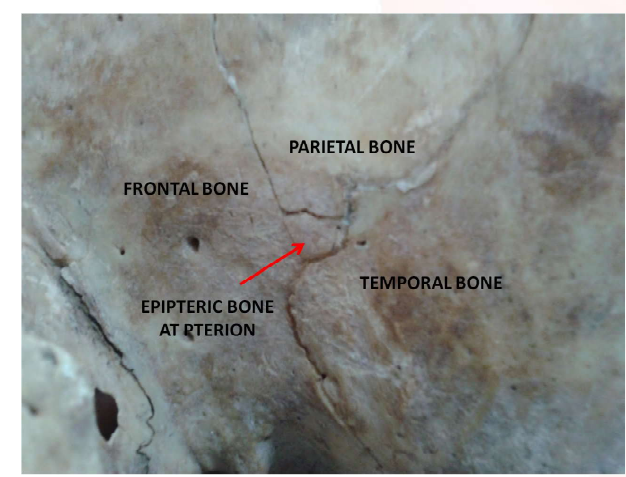

Fig. 4: Position of Pterion (P) from superior margin of zygomatic arch (ZA) and posterolateral margin of frontozygomatic suture (FZS).

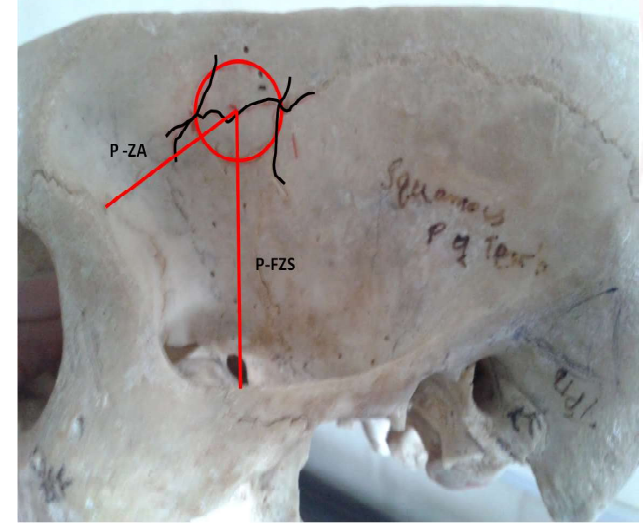

Fig. 5: Position of Pterion (P) on inner aspect of skull from lateral margin of optic canal $(\mathrm{OC})$ and lateral end of sphenoidal ridge (SR).

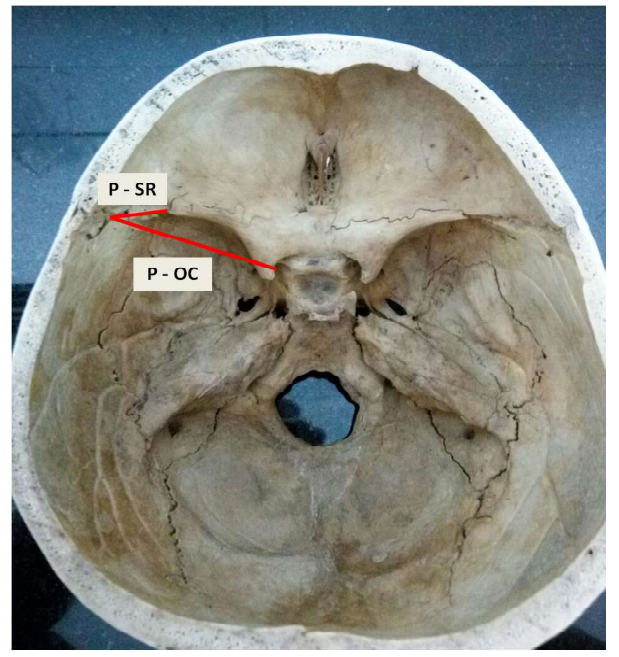

Fig. 6: Asterion (Type 2).

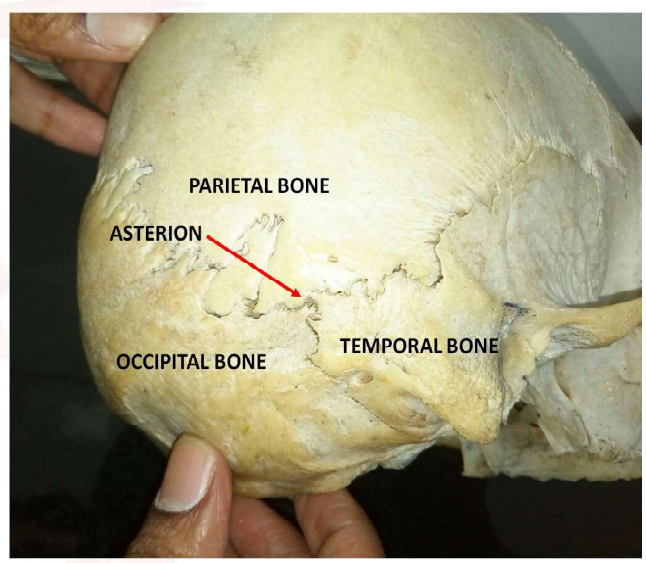

\section{RESULTS}

All four types of pterion were observed in the 78 skulls analyzed. Sphenoparietal was the predominant type of pterion observed. Stellate type was least common. Bilateral asymmetry was seen. (Table 1)

The position of pterion with respect to bony landmarks was calculated. Mean distances from centre of pterion were 38.15+/-3.67 (right side) and 36.69+/-3.64 (left side) superior to zygomatic arch; $29.35+/-3.60$ (right side) and 27.37+/-5.80 (left side) posterior to fronto-zygomatic suture, $8.80+/-2.25$ (right side) and $8.66+/-2.21$ (left side) from lateral edge of sphenoidal ridge and 39.58+/-3.49(right side) and 38.84+/-3.48 (left side) from lateral margin of optic canal. Mean length of pterion was $14.06+/-2.96$ on right side and $14.58+/-4.06$ on left side. Mean thickness of skull at pterion was $5.72+/-1.41$ on right side and $5.77+/-1.29$ on left side. (Table 2 )

Both types (Type 1 and type 2) of asterion were 
observed in the skulls, with sutural bone (Type 1 ) occurring in $13.46 \%$ of asterion. (Table 3 )

Table 1: Prevalence of various types of Pterion.

\begin{tabular}{|c|c|c|c|}
\hline Pterion type & $\begin{array}{c}\text { Right } \\
\mathrm{n}=78\end{array}$ & $\begin{array}{c}\text { Left } \\
\mathrm{n}=78\end{array}$ & Both sides \\
\hline Sphenoparietal & $66(84.62 \%)$ & $63(80.77 \%)$ & $82.70 \%$ \\
\hline Frontotemporal & $3(3.84 \%)$ & $2(2.56 \%)$ & $3.20 \%$ \\
\hline Stellate & $1(1.28 \%)$ & $3(3.84 \%)$ & $2.56 \%$ \\
\hline Epipteric & $8(10.26 \%)$ & $10(12.2 \%)$ & $11.54 \%$ \\
\hline
\end{tabular}

n = sample size

Table 2: Relative position, length and position of Pterion.

\begin{tabular}{|c|c|c|}
\hline Distance & Right (Mean+/-SD) & Left (Mean+/-SD) \\
\hline Length (mm) & $14.06+/-2.96$ & $14.58+/-4.06$ \\
\hline Thickness (mm) & $5.72+/-1.41$ & $5.77+/-1.29$ \\
\hline P-ZA (mm) & $38.15+/-3.67$ & $36.69+/-3.64$ \\
\hline P-FZS (mm) & $29.35+/-3.60$ & $27.37+/-5.80$ \\
\hline P-SR (mm) & $8.80+/-2.25$ & $8.66+/-2.21$ \\
\hline P-OC (mm) & $39.58+/-3.49$ & $38.84+/-3.48$ \\
\hline
\end{tabular}

$\mathrm{P}-\mathrm{ZA}=$ Pterion to zygomatic arch; P-FZS = Pterion to frontozygomatic suture;

$\mathrm{P}-\mathrm{OC}=$ Pterion to optic canal; $\mathrm{P}-\mathrm{SR}=$ Pterion to sphenoidal ridge; $\mathrm{SD}=$ Standard deviation

Table 3: Prevalence of type of Asterion.

\begin{tabular}{|c|c|c|c|}
\hline $\begin{array}{c}\text { Type of } \\
\text { asterion }\end{array}$ & $\begin{array}{c}\text { Right } \\
\mathrm{n}=78\end{array}$ & $\begin{array}{c}\text { Left } \\
\mathrm{n}=78\end{array}$ & $\begin{array}{c}\text { Mean } \\
\text { occurrence }\end{array}$ \\
\hline Type 1 & $11(14.10 \%)$ & $10(12.82 \%)$ & $13.46 \%$ \\
\hline Type 2 & $67(85.90 \%)$ & $68(87.18 \%)$ & $86.54 \%$ \\
\hline
\end{tabular}

\section{DISCUSSION}

The commonest type of pterion in the present study is spheno-parietal type which is similar to that reported in 19 studies mentioned in Table 4 , though the prevalence varies from $66 \%$ to 96 $\%$. The second commonest is epipteric type of pterion in the present study and the same has been reported in studies conducted by Saxena (1988), Manjunath (1993), Ankur Zalawadia (2010), W Apinhasmit (2011), Mary Antony Praba (2012), R Sudha (2012) \& Prashant Natekar (2016); the prevalence varying from $4 \%$ to $51.5 \%$. The third commonest type is fronto-temporal type of pterion coinciding with studies conducted by Saxena (1988), Oguz (2004), Saxena RC (2008), Mwachaka PM (2009), Hussain Saheb S (2011), Sunday A. Adejuwon (2013); the prevalence varying from $2.4 \%$ to $7.5 \%$. The fourth \& last type of pterion in present study was stellate type, prevalence of which ranged from $0.4 \%$ to $5.6 \%$ \& coincided with studies conducted by Saxena (1988), Manjunath (1993), Ankur Zalawadia (2010) \& W Apinhasmit (2011). (Table 4)

Table 4: Comparison of types of Pterion in different populations.

\begin{tabular}{|c|c|c|c|c|c|}
\hline \multirow{2}{*}{ STUDY } & & \multicolumn{4}{|c|}{ PTERION } \\
\hline & $\begin{array}{c}n=5 a m p l e \\
\text { size }\end{array}$ & $\begin{array}{l}\text { Spheno- } \\
\text { parietal }\end{array}$ & $\begin{array}{c}\text { Fronto - } \\
\text { temporal }\end{array}$ & Stellate & Epipteric \\
\hline Australian aborigines - Murphy- (1956) [8] & 388 & $73 \%$ & $7.50 \%$ & $18.50 \%$ & $1 \%$ \\
\hline Nigerian - Saxena et al. (1988) [9] & 40 & $87.79 \%$ & $10.11 \%$ & $5.06 \%$ & $3.79 \%$ \\
\hline Indian - Saxena et al. (1988) [9] & 72 & 95.3 & 3.46 & 1.38 & 11.79 \\
\hline Japanese - Matsumura (1991) [10] & 614 & $79.10 \%$ & $2.60 \%$ & $17.70 \%$ & $0.60 \%$ \\
\hline Manjunath et al. (1993) [11] & 172 & $93.55 \%$ & $3.52 \%$ & $2.93 \%$ & $17.30 \%$ \\
\hline Asala et al. (1996) [12] & 212 & 82.1 & 23.6 & - & 5.7 \\
\hline Korean - Lee et al. (2001) [13] & 149 & 76.5 & - & - & 40.3 \\
\hline Turkish - Ersoy (2003) [6] & 300 & $87.35 \%$ & $3.47 \%$ & $8.98 \%$ & $0.20 \%$ \\
\hline Turkish males - Oguz (2004) [14] & 26 & $88 \%$ & $10 \%$ & $2 \%$ & $0 \%$ \\
\hline Saxena RC et al. (2003) [15] & 203 & $84.72 \%$ & $10.01 \%$ & $5.17 \%$ & - \\
\hline Kenyans - Mwachaka PM (2009) [16] & 79 & $66 \%$ & $15 \%$ & $12 \%$ & $7 \%$ \\
\hline Ankur Zalawadia et al. (2010) [4] & 42 & 91.7 & 2.4 & 1.2 & 4.8 \\
\hline Hussain Saheb Set al. (2011) [17] & 125 & $69.25 \%$ & $17.35 \%$ & $9.70 \%$ & $3.70 \%$ \\
\hline Thai - W Apinhasmit et al. (2011) [18] & 268 & $81.20 \%$ & $1.10 \%$ & $0.40 \%$ & $17.40 \%$ \\
\hline Mary Antony Praba et al. (2012) [19] & 50 & $74 \%$ & $3 \%$ & $9 \%$ & $14 \%$ \\
\hline Sunday A Adejuwon et al (2013) [20] & 37 & $86.10 \%$ & $8.30 \%$ & $5.60 \%$ & nil \\
\hline R. Sudha et al. (2013) [21] & 150 & $80 \%$ & $3 \%$ & $5.30 \%$ & $11.30 \%$ \\
\hline Hariprasad et al. (2015) [22] & 60 & $89.20 \%$ & $3.30 \%$ & $5 \%$ & $2.50 \%$ \\
\hline Prashant Natekar et al. (2016) [23] & 150 & $85.33 \%$ & $8 \%$ & $10.60 \%$ & $51.54 \%$ \\
\hline PRESENT STUDY & 78 & $82.70 \%$ & $3.20 \%$ & $2.56 \%$ & $11.54 \%$ \\
\hline
\end{tabular}

It has been postulated that several genes acting in cranial suture growth and morphogenesis are involved in regulating pterion variability. This includes the MSX2 gene, which plays a crucial role in craniofacial morphogenesis by influencing fusion of sutures through a homeodomain transcription factor. The development of calvarial bones is tightly coordinated with the growth of the brain, giving rise to the varying sutural patterns of pterion. The most common type of pterion in modern humans, bonobos, orangutans \& gibbons is spheno-parietal type \& in chimpanzees \& gorillas it is fronto temporal type [3]. This suggests an evolutionary basis as well for pterion morphology, corresponding to an increase in size of human brain [24].

A detailed knowledge of type of pterion and its location in relation to surrounding bony landmarks and underlying soft tissues is important in pterional approaches especially with respect to neurosurgery \& vascular microsurgery $[6,20]$. A minimally invasive procedure is the main objective in neurosurgery in the successful treatment of pathologies [4]. The incidence of sutural bone at pterion is high in Indians, and the presence of sutural bones may or may not 
be associated with cranial \& central nervous system anomalies [25].

The type 2 asterion was found in present study \& all studies reported in Table 5 with the prevalence varying from $76.85 \%$ to $92.5 \%$. The present study findings are similar to the studies reported by Berry (1967) in Egyptians \& Indian Burma population. (Table 5) It has been postulated that the formation of sutural bones at asterion may be a result of physiological processes that are genetically determined. However, there may also be the presence of pathological influences like hydrocephalus [16].

Table 5: Types of asterion in different populations.

\begin{tabular}{|c|c|c|c|}
\hline \multirow{2}{*}{ STUDY } & n=Sample & \multicolumn{2}{|c|}{ ASTERION } \\
\cline { 3 - 4 } & size & TYPE I & TYPE II \\
\hline North Americans- Berry - 1967[26] & 50 & $12 \%$ & $88 \%$ \\
\hline South Americans- Berry - 1967[26] & 53 & $7.50 \%$ & $92.50 \%$ \\
\hline Egyptians- Berry - 1967[26] & 250 & $14.40 \%$ & $85.60 \%$ \\
\hline Indians - Burma- Berry - 1967[26] & 51 & $14.70 \%$ & $85.30 \%$ \\
\hline Indians - Punjab- Berry - 1967[26] & 53 & $16.90 \%$ & $83.10 \%$ \\
\hline Turks- Gumusburun - 1997[16] & 302 & $9.92 \%$ & $90.08 \%$ \\
\hline Kenyans- Mwachaka - 2009[16] & 79 & $20 \%$ & $80 \%$ \\
\hline Indians-Hussain Saheb S- 2011[17] & 125 & $23.15 \%$ & $76.85 \%$ \\
\hline PRESENT STUDY & 78 & $13.46 \%$ & $86.54 \%$ \\
\hline
\end{tabular}

\section{CONCLUSION}

The present study is in agreement with previous studies on different populations and concludes that the morphologic and morphometric patterns of pterion and asterion in skulls of Indian origin are similar to those in other populations.

Findings of the present study may be correlated with other modern commonly used modalities such as radiological analysis to better predict the structure of pterion and asterion and allow better surgical safety and efficacy.

\section{Conflicts of Interests: None}

\section{REFERENCES}

[1]. Williams PL, Bannister LH, Berry MM, Collins P, Dyson M, Dussek JE, et al. The skull. In. Gray's Anatomy, 38th ed. London: Churchill Livingstone; 1995. p. 560.

[2]. Urzi F, Lannello A, Torrisi A, Foti P, Mortellaro NF, Cavallaro M. Morphological variability of pterion in the human skull. Ital.J.Anat.Embryol 2003; 108 (2): 83-117.

[3]. Q.Wang, L. A. Opperman, L. M. Havill, D. S. Carlson, and P. C. Dechow. Inheritance of sutural pattern at the pterion in rhesus monkey skulls. Anatomical Record A 2006;.vol. 288(10):1042-1049,
[4]. Ankur Zalawadia, Jignesh Vadgama, Srushti Rupar elia, Shailesh Patel, S.P.Rathod, S.V.Patel. Morphometric study of pterion in dry skull of Gujarat region NJIRM 2010;1(4):25-29.

[5]. Lovejoy CO, Meindl RS, Mensforth RP, Barton TJ. Multifactorial determination of skeletal age at death: a method a blind tests of its accuracy. Am J Phys Anthropol 1985;68:1-14.

[6]. Ersoy M, Evliyaoglu C, Bozkurt MC, Konuskan B, Tekdemir I, Keskil IS. Epipteric bones in the pterion may be a surgical pitfall. Minim Invasive Neurosurg 2003;46:363-5.

[7]. Sucharitha. A, Dr. Roshni Bajpe. Study of anatomic position of Pterion in dry human skulls in Karnataka Sch. J. App. Med. Sci., 2016; 4(9B):3272-3276.

[8]. Murphy T. The pterion in the Australian aborigine. Am J Phys Anthropol 1956;14:225-44.

[9]. Saxena SK, Jain SP, Chowdhary DS. A comparative study of pterion formation and its variations in the skulls of Nigerians and Indians. Anthropol Anz 1988;46:75-82.

[10]. Matsumura G, Kida K, Ichikawa R, Kodoma G. Pterion and epipteric bones in Japanese adults and fetuses with special reference to their formation and variations. Kaibagaku Zasshi 1991;66:462-71.

[11]. Manjunath K.Y. \& Thomas I.M., Pterion variants and epipteric ossicles in South Indian skulls, J Anat Soc India 1993;42:85-94.

[12]. Asala SA, Mbajiorgu FE. Epigenetic variation in the Nigerian skull: sutural pattern at the pterion. East Afr Med J 1996;73:484-6

[13]. Lee UY, Park DK, Kwon SO, Paik DJ, Han SH. Morphological analysis of the pterion in Korean. Korean J Phys Anthropol 2001;14:281-9.

[14]. Oguz O, Sanli SG, Bozkir MG, Soames RW. The pterion in Turkish male skulls. Surg Radiol Anat 2004;26:220-4.

[15]. Saxena RC, Bilodi AKS, Mane SS, Kumar A. Study of pterion in skulls of awadh area-in and around Lucknow. Kathmandu Univ Med J 2003;1:32-33.

[16]. Mwachaka PM, Hassanali J, Odula P. Sutural morphology of the pterion and asterion among adult Kenyans. Braz J Morphol Sci 2009;26:4-7.

[17]. S Hussain Saheb, G.F.Mavishetter, S.T.Thomas, L.C.Prasanna, P.Muralidhar. Anatomical position of pterion among the Indian for lateral skull approach. Biomedicine 2010;30 (3):391-393.

[18]. W. Apinhasmit, S. Chompoopong, V. Chaisuksunt, P. Thiraphatthanavong, and N. Phasukdee, Anatomical consideration of pterion and its related references in thai dry skulls for pterional surgical approach, Journal of the Medical Association of Thailand 2011;94(2):205-214.

[19]. Anatomy Praba Antony Mary A and Venkatramaniah . Journal of Pharmaceutical and Biomedical Sciences. 2012;21(04):1.

[20]. Sunday A. Adejuwon, Funmilayo E. Olopade, Modupe Bolaji. Study of the Location and Morphology of the Pterion in Adult Nigerian Skulls. ISRN Anatomy 2013; Volume, Article ID 403937, 4 pages. 
[21]. R. Sudha, C. Sridevi, M. Ezhilarasi. Anatomical variations in the formation of pterion and asterion in South Indian population. Int J Cur Res Rev, May 2013;05(09):92-101.

[22]. Hariprasad, NK Bezbaruah, Anushu Mishra, Parmatma Prasad Mishra. Morphometric analysis of pterion: A clinic-Anatomical study in North Indian dry skulls. Innovative journal of medical and health science 2015;5(5):201-205.

[23]. Prashant E Natekar, Fatima M DeSouza, Suhit P Natekar. Pterion: An anatomical variation and surgical landmark. Indian Journal of Otology, April 2011;17(2):83-85.
[24]. Ashley-Montagu FM. The anthropological significance of the pterion to the primates. Am J Phys Anthropol 1933;18:159-336.

[25]. Satheesha NAYAK B, Soumya KV. Unusual sutural bones at pterion. International Journal of Anatomical Variations 2008;1:19-20.

[25]. Berry, AC. and Berry, RJ. Epigenetic variation in the human cranium. Journal of Anatomy 1967;101:361379.

How to cite this article:

Vivaan Dutt, Veena Vidya Shankar, Shailaja Shetty. MORPHOMETRIC STUDY OF PTERION AND ASTERION IN ADULT HUMAN SKULLS OF INDIAN ORIGIN. Int J Anat Res 2017;5(2.2):3837-3842. DOI: 10.16965/ijar.2017.198 